\title{
A CASE OF ATAXIA OF THE WALLENBERG'S SYNDROM OWING TO THROMBOANGIITIS OBLITERANS
}

By

T. MUKASA

\section{From the Department of Otorhinolaryngology Nagasaki University School of Medicine (Director: Prof. T. Goto)}

\begin{abstract}
A case of the Wallenberg's syndrom owing to thromboangiitis obliterans, A male aged 48 years, was reported and the author studied particularly on disturbans of equilibrium by functional test, from which could not find the findings of celleberal lesion and could suspect vestibular disturbans.

Concerning the obliterated vessels, $A$. vertebralis and $A$. cerebellaris inferior posterior were confirmed by angiography.
\end{abstract}

\section{閉鎖性血栓血管炎による平衡障害（ワレンベルヒ氏 症候群) の一例}

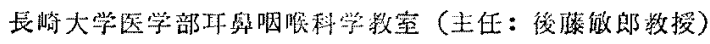

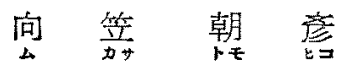

\section{緒亳}

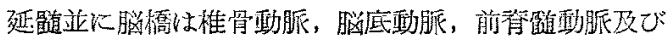
その分技に上り血行をうけている。これらの血管煌挂 又性血栓をきたて血管腔が開鎖すると，それによって

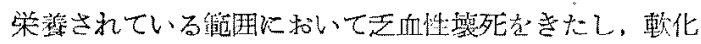

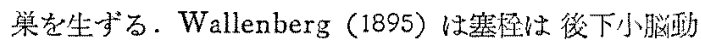
脈㲹起ることが多く，これによつて乫登的に一侧のV，

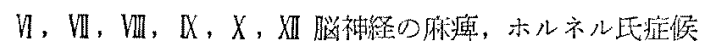

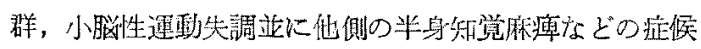
群を呈することを報告した。そ後 Merrit, Finland， Andre, Thomas, Hamet, Bars, 柳原, 做 (1949), 会田（1951）等む同様の症候群について報告し，これが 一般に Wallenberg 症候确と呼ばれるにいたつた。

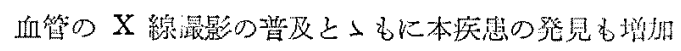

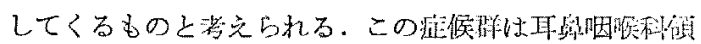

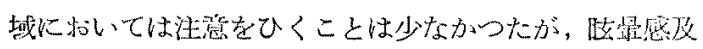

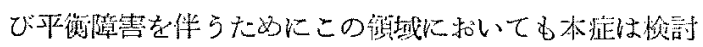

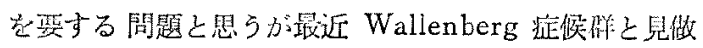
ざれる一症例を観察したので報告する。

\section{症例}

患诸：久O政○48才去社員

主訴：眩最，非画留，进動失調
既往歷：28 才のとき右急性中耳炎.38 寸のとき自発 脱誼のため右第》指及び第》指，左拇趾及び第』趾の切 断受けた。

家族歴：特記す心的ものはない。

現病歴：昭和 34 年 10 月 25 日, 自転車飞て通行中, 略最感あり右側に倒れそうになつたので直ちに降車した

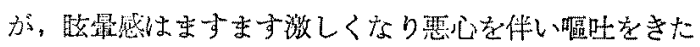
し，路傍に一時間程休んでいた，その䦌に嘔吐は約 10 回あつたが吐物は㖇液と食物のみであつた。立ら上がろ うとしたが身体の自由诗さかないに気付いた。丁度ひ

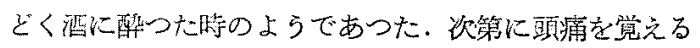
に至つたが急識は明璄であつた。雨行人を呼ぼうとした が声がでなかつた，家に暹ばれて寝ていたが影重感，眩

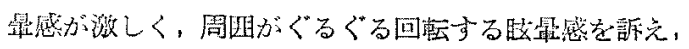
また複視が西り，右眼瞼快下瑇してものがよくみ光なか

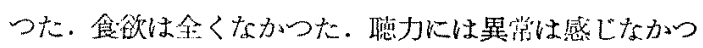

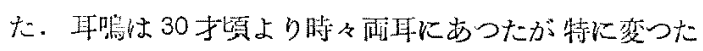
ように思总なからたという。

某病院に入院して 2 カ月余の治療をうけたがよくなら ないので摁院した。昭和35年1月12日，当科を訪づれ 入院した。

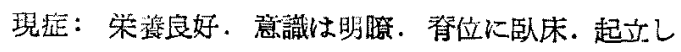


ようとすると右側に倒れる。閉眼では身体の動摇が更に

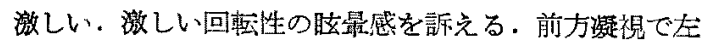
に向ら自発性限振あり，頭を右傾したり，右下側位飞や

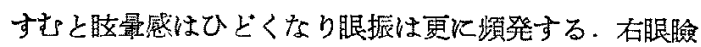
は軽度に下垂, 右角脱反射消失, 眼底恃再腿之もに異常 はない，複視があつて殊右方を向い炕時溞い，右眼

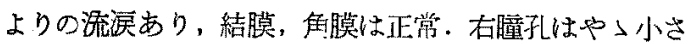

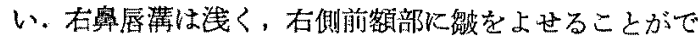
きない，頼をふくらませることも口笛を吹くこともでき

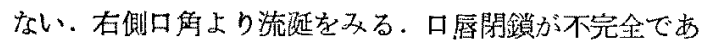

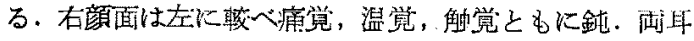
の鼓膜は正常．鼻腔にも著変を認めら机ない，嗅党も正 常、舌を提出させると石に傾き，線維性収縮を及る。石

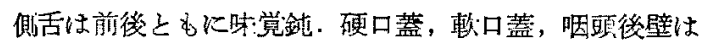

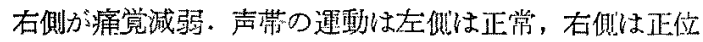

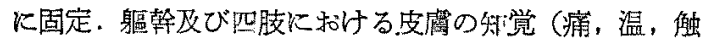

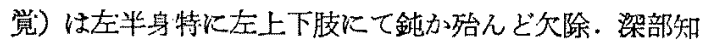
覚怔常．橈骨反射，尺骨反射ともに正常．瞵蓋腱反 射、アキレス腱反射は左右ともに娍弱，右側上肢，下肢 见軽度の運動失調をみる，右上肢は指指試跧，指鼠試駼 は軽度に抵分，また右下肢では滕踵試験は抽劣である。 フヂフドコキネーゼは認められない，握力右 $13 ，$ 左 30， 但し右第 I指，第四指恃欠損している.

ピロカルピンテストでは発汗は右顔面にみられず，左 顔面に著明に現れ，身區幹四肢では発汗は著明でなく，左 右差も認められない，流趜は注射後一時間の総量約 120 cc であった. アドレナリンテストは㓌性.

脈搏は右橈骨動脈の脈搏は減蒻し 殆んざ測定できな い. 左橈骨動脈の脈搏は緊張, 大きさ, 調律, 数ともに 正常である. 血圧は左側 $144 \sim 88 \mathrm{mmHg}$ 右側は 测定で きない，呼吸は正常で心臓所見，胸部所見，腹部所見に はいづれる異常は認められない。

血液梅毒反応陰性，赤血球数 454 万，白血球数 几 万， 血色素量 $98 \%$ ，血液像は著变ない，

脳等酭液は压 $160 \mathrm{~mm} \mathrm{H}_{2} \mathrm{O}$ (坐位)，ノソネアペルト $1(-)$, パンヂーE反応 (一), 細胞数 $2 / 3$ (淋巴球), 糖 $55 \mathrm{mg} / 100 \mathrm{cc}$ ，口民反応㓌性。尿検盁蛋白 $(-)$, 糖定 性 $0.1 \%$.

経遄： 1 月中旬 (発病後約 2 力月半), 激しい脑昆感 专り，自発性眼振は方方凝煶で左に向い水平性である。 右下側臥位をとると左に向う腿振は覑発する。缩台上に 手を支えなくては起立できない，聴力障害は訴克ない， 食欲はあるが葴下愺害を訴える。
2 月上旬，両㒋松葉杖をついてゆつくり步けるよう になる。瞙最感は少し軽くなつたが，左に向う水平性の

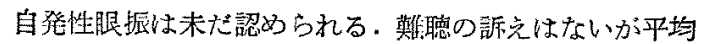
聴力損失にて気導右耳 $18.7 \mathrm{db}$, 左耳 16.2db の低下を友 た。骨導では殆んど異常がない(第 1 図)，右側耳鳴を

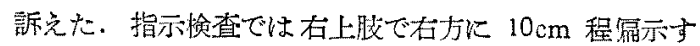

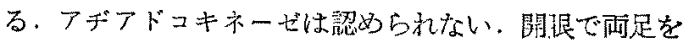
開けば立てるが動墇あり，网足をとる克ると更に動摇は 激しくなり，閉眼では右後方に倒れる（ロンベルグ現象 陽性). 血圧は左 $140 \sim 80 \mathrm{mmHg}$, 右測定できない。

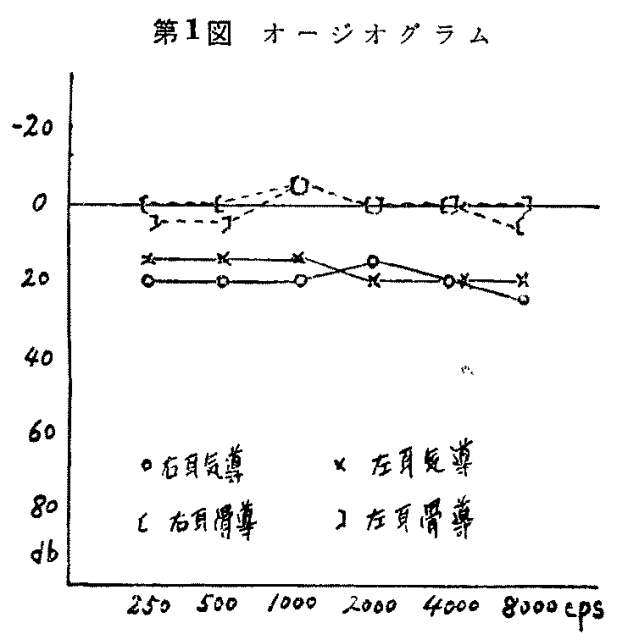

温度剩㦸検查はフレンツェル氏镜による肉眼的な钼察 法で行い, 左耳注入 $30^{\circ} \mathrm{C}$ の冷水 $20 \mathrm{cc}$ 潜伏時間 11 秒 中等大の右们向 5 水平性眼振起り，持続時間 146 秒，10 秒間飞 4 数之られる. 次で 40 秒間自発性腿浱は消失し。 眼球は一時静止するが 再び左に向う自発性眼振が 現れ る.

2月下旬，右側顔面麻痺は軽度になる，前額部に皱を よせらるようになり，右煩部に食物もたまらなくなつて

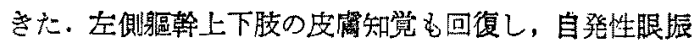
は左に向い水平性で辛うじて認められる程度となる。開 眼で起立可能となつたが，閉眼では末だ右方に倒れる。 歩行は跛行し，両側松葉杖を使つて歩く．単脚直立， 足踏㭘查はできない，畵字榆查は開眼では正常，遮眼で

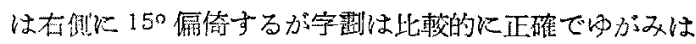
みられない，指示梌查でけ著变好認奶られない

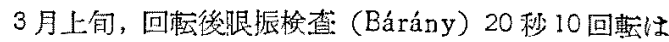
第1表の如くである.自発性腿振は未だ左に向う水平性 眼振を辛うじて認められる.温度刺战梌查. 左耳 $30^{\circ} \mathrm{C}$ 
冷水並に右耳 $44^{\circ} \mathrm{C}$ 温水各 $20 \mathrm{cc}$ (8 10 秒間) 注入の 成績は第 2 表の如くである. 血纴は土 125〜80 $\mathrm{mmHg}$ ， 右側では測定できない，脈搏は左橈骨動脈では正常，右 橈骨動脄では触れない。

3月中旬，右眼睑下垂はみみられなくなり，右手に杖を ついて步行しらるに至る。右声帯も多少動き，言藮も明 瞭となる、退院。

第 1 表 回 転 後 眼 桭

\begin{tabular}{|c|c|c|c|}
\hline 回蝴间 & 䄑向 & 性稘 & 持統晓间 \\
\hline 右 & $\rightarrow$ & 蚛等大 & 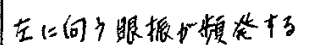 \\
\hline 左 & $\leftarrow$ & 中第大 & 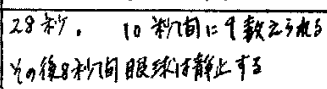 \\
\hline
\end{tabular}

第 2 表 温 度 性 腿 振

\begin{tabular}{|c|c|c|c|c|c|c|}
\hline & 狂 & 谁傎 & 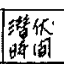 & 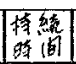 & 析软 & との復 \\
\hline 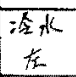 & $<$ & 中萃大 & 10 & 125 & $4 / 1 \%$ & 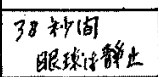 \\
\hline $\begin{array}{l}\text { 温水 } \\
\text { 在 }\end{array}$ & $\leftarrow$ & 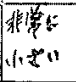 & 21 & 35 妆 & $2 / 10$ & 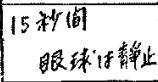 \\
\hline
\end{tabular}

考按

(1) 病巣部位並に本症々神経核との関保

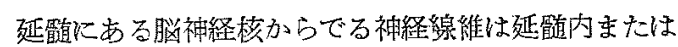
脳橋内を通つて末梢に達する.大脳から脳神経核に達す

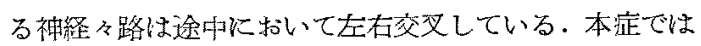
右顔面の知觉麻瘦, 左側半身の知賞麻瘨があるから病栄

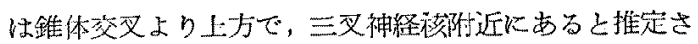
れる。この核より上方であれば，三叉神経は交攴するか ら病栄は延噵の三叉神経校附近（右側）之考学られる。

本症の症状と神経核並侸神経々路の関係を考光ると，

前庭神経核一眼振，眩最感

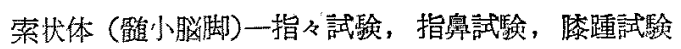
の拙贫, 上下胶の運動失䛿

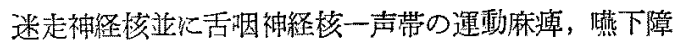
害, 舌の後 $1 / 3$ の味覚障害

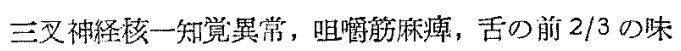
觉障害

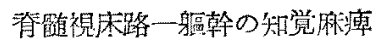

舌下神経核一舌の運動障害

顔面神経一顔面神経麻瘦症状

交感神経一ホルネル氏症侯群

などの症候がおこつてきたるのと考光られる。

迷路性平衡反射の伝導路の未梢枝は前庭の感覚上皮に
はじまり内耳道底にある前庭神経節にて第 2 Neuron として前庭神経となり延踏に入つて菱形鹤にある同側の 終止檬に終る。更にこの終止核から䯣小脳脚を経て小腷 に到る。本症では約 6 力月間持続した回転性の眩最，群 側炕向う水平性の大きな自発性眼振が認められた。 右下側卧位飞やすむと健側们向う水平性の腿振は嚬発持 続した. 発病時には悪心, 嘔吐を伴つたがその後性こ らなくなつた．起立㭘查は初わは開眼でも起立できなか つた．閉眼では身体の動摇が激しく，右後方に熲倒し た. 単脚直立，足踏榆查はできなかつた。

右上肢で指指試験, 指藇試験は軽度に拙劣, 右下凌で 陵踵試験の拙劣なことは運動失調の存在を意味:し小脳泟 状と考光られる。しかし発病後約4 力月目に行つた遮眼 書字㭘查では右側への偏倚がみられたが，文字の乱れは 認められなかつた。

延的道の前庭神経核, 䯣小脳脚の病変によつておこつて きた中枢迷路性腿桭及び運動失調であるが，病勢の軽減 と〉るに平衡障害る轅快してさている。

聴力検查刀 結果伝音性難聴を示し，また30才頃上り

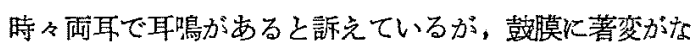

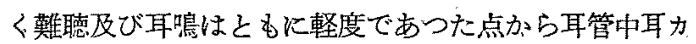

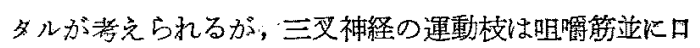
蓋畍張筋には翼口蓋神経節を介乙て, 鼓脱張筋には耳神 経節を介して支配しているので鼓脱張筋麻㾇む加つてい ると思われる。

（2）血管腔閉鎖の原因

延鹃に栄咅を与克る動脈に塞挃または血柽を生じる原 因としては，心内膜炎，心弁腰症，動脈硬化症，梅蛀な どが考它られる。会田氏は慢性骨䯙焱患者に本症が出現 したと報告した。本例では 1.月下旬脳動脈熶影を行い,右

第 2 図椎骨動脈, 憏底動脈

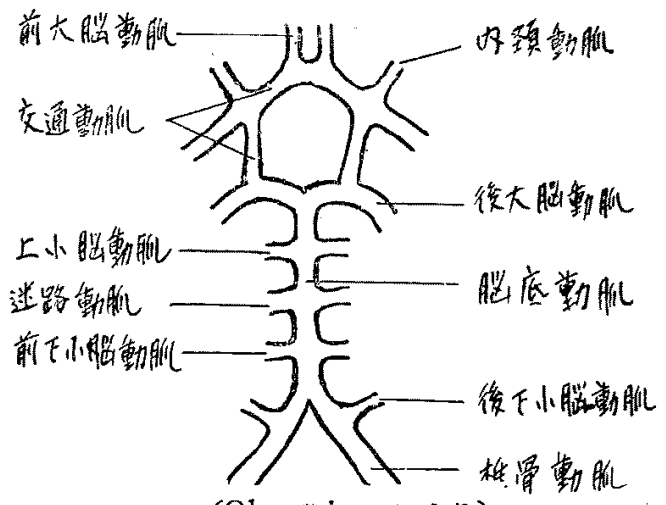

(Obersteiner Kょる) 
脳椎骨動脈並に後下小脳動脈の閉鎖を見出した。また指 趾切断の既往歴があり，右橈骨動脈の脈搏が非常に減弱 していたことなどから閉鎖性血栓血管炎(Bürger 病)が 考えられる．更にこのことは（イ）血圧は正常である から出血は考兄られない（口）外傷がないので脂肪栓 塞は考兄られない（ハ）心臓に所見がみられない （二）ワツセルマン反応陰性.（ホ）リコールに 異常が ない（へ）疾患は一挙卒中型に急激におこつたことな どからも推定できる。

閉鎖性血栓血管炎の原因は不明であるが中辀, 感染, 体質, 寒冷など挙げられ, 動脈の内臊袖胞の增殖と血烃 が認められている。

(3) 経過について

脳底の動脈は第 2 図の如くであるが橋の下端で左右の 椎骨動脈が合して脳底動脈々なつている．本例が慢性の 経過をとり，また症状が軽減したのは副行動脈枝の新生 によると考觉らる。
結語

右側椎骨動脈，後下小脳動脈の閉塞によりおこつてき た症状，経過，病巣部位及び原因などを観察した。

$$
\text { 文献 }
$$

1) Bumke a. O. Foerster: Handbuch d. Neurolog II, 1937. 2) Wallenberg: Arch. f. Psychiatr. 27: 504，1895.3）柳原亮一. 高柳日出臣： ワレンペルヒ 症候群の一例, 耳鼻臨, 43, 3, 117，(25.3). 4) 会田勘 二：慢性骨㗓炎患者に 発生せる Wallenberg 症候群

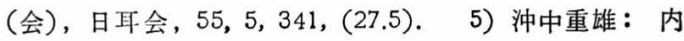
科書上巻, 南山堂.

本症は一部村上（大村市民）飞上り臨床神経 病学会第 1 回 (福岡), 本保 (長大放)により日 医放射線学会九州地方会に発表した。

（原稿到着 $=$ 昭和 35.8.10 日）
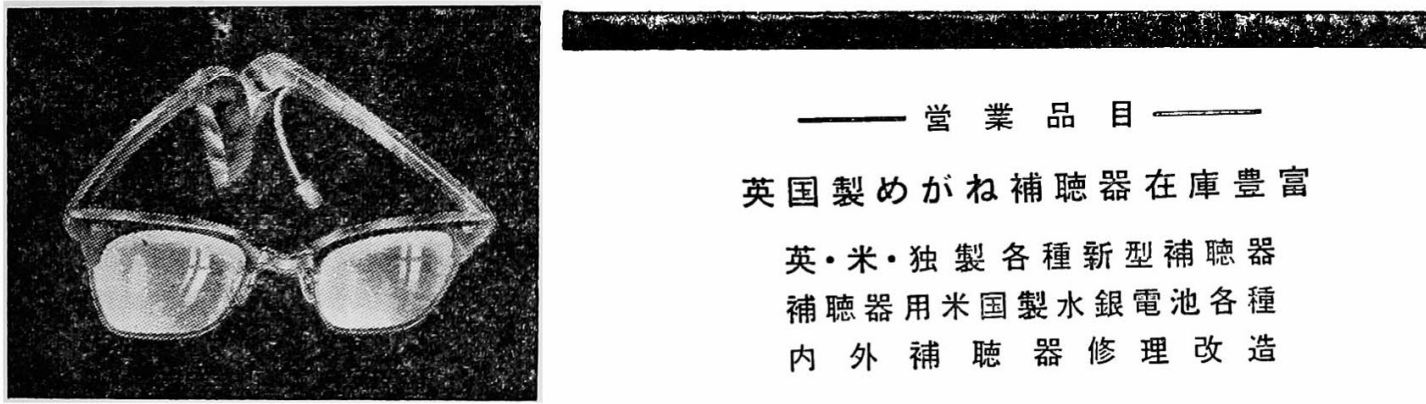

一営業品目

英国製めがね補聴器在庫豊富

英・米・独製各種新型補恥器

補聴器用米国製水銀電池各種

内外補聴 器修 理 改造

\section{補聴器の御用はどうぞ日本補聴器へ}

補聴器輸入販売専用の店

カタログ贈呈

\section{日本補聴器販売株式会社}

東京都千代田区神田酸何台三八十一

電話 (291) 0080 振替 東京 77872 